\title{
IMPLICATIONS RESULTING FROM THE STUDY OF FLUID INCLUSIONS IN THE SHEAR ZONE-TYPE GOLD MINERALIZATION FROM BOZOVICI (BANAT) AND SOMEȘUL RECE (GILǍ U MOUNTAINS) ${ }^{1}$
}

\author{
VASILE POMÂRLEANU ${ }^{2}$ and IOAN MÂRZA ${ }^{3}$ \\ In memoriam Prof. Valeriu Lucca
}

\begin{abstract}
The paper presents the results of a study on fluid inclusions (petrography, chemistry, Th, Td) from the gold-containing quartz in the shear zone type mineralizations from Bozovici (Banat) and Someșul Rece (Gilă u Mountains). Four types of fluid inclusions were identified: $\mathbf{A}$ - aqueous, AS - aqueous with efflorescences and crystals of nahcolite, $\mathbf{C}$ - monophasic and biphasic containing $\mathrm{CO}_{2}$, and $\mathbf{A C}$ - aqueous solutions with $\mathrm{CO}_{2}$. Microthermometry (Th and Td) indicated homogenisation temperatures of nahcolite between $136-260^{\circ} \mathrm{C}$, total homogenisation temperatures of $283-390^{\circ} \mathrm{C}$, and a maximum temperature (Td) between $380-420^{\circ} \mathrm{C}$. The molar content of the $\mathrm{CO}_{2} / \mathrm{H}_{2} \mathrm{O}$ ratio varies between $0.35-0.72$; salinity ranges between $2-14$ wt \% equivalent. Gold is intimately disseminated in quartz (in both studied occurrences), but also it is associated with sulphides, especially pyrite (Bozovici) and chalcopyrite (Someșul Rece).
\end{abstract}

Key words: fluid inclusions, shear zones, nahcolite crystals, Th, Td, molar ratios $\mathrm{CO}_{2} / \mathrm{H}_{2} \mathrm{O}$, wt \% salinity.

Recently, shear zone-type gold mineralizations associated to metamorphic complexes in the Carpathians of Romania were also studied for their fluid inclusion content. The main goals were to establish the formation temperatures (Întorsureanu et al., 1985), the erosional level of the gold-containing ore bodies (Popescu and Sava, 1994) and the chemistry of the inclusions (Popescu and Predeteanu, 1999; Predeteanu and Popescu, 2000) etc. Among the numerous gold occurrences genetically associated to shear zones structures from the crystalline terrains from the Romanian Carpathians, our study referred only to the ones from Bozovici (Banat) and Someșul Rece (Gilă u Mountains). The paper brings new results concerning geothermometry, without going into the general geological and petrographical aspects of the studied areas, previously presented elsewhere.

\footnotetext{
${ }^{1}$ Presentation on the occasion of the Anniversary Symposium "Prof. Valeriu Lucca (1901-1969) - 100 years from his birth", 1-2 Junie 2001, Cluj-Napoca.

2 Luncșoara Str., 1, BI. 52, Ap. 35, Sector 2, București 10.

${ }^{3}$ Babeș-Bolyai University, Faculty of Biology and Geology, Department of Geology, Str. M. Kogă Iniceanu, 1, Cluj-Napoca
} 


\section{The gold-containing mineralization from Slă tinic (Bozovici, Banat).}

The gold-containing quartz from Slă tinic Valley (an effluent of Miniș Valley) was first identified in 1922, due to the discovery of a gold-containing quartz block in the Badenian conglomerates outcropping in the region, overlaying crystalline schists (amphibolite, amphibole schist). As a consequence, intensiveprospecting activity started, followed by exploration with mine works located upstream from the confluence of Slă tinic Valley with Miniș Valley (performed by "Mica" Society from Brad). Lucca (1949) ${ }^{4}$ presented a brief description of the mineralization in a geological report, together with a sketch of the mining works showing the lens-shape of the ore associated to the metamorphic schists. The previously mentioned geological report contains also several profiles that illustrate the underground situation. One year later (Lucca, 1950) ${ }^{5}$ the same group of authors proposed that the mining activity should be stopped based on the facts that the mineralised body presented significant discontinuities in the depth and the contents of gold and silver were considered not worthy economically.

The gold mineralization under discussion consists of massive quartz incorporating fine disseminated particles of gold and sulphides; accidentally small calcite geodes were also noticed. Macroscopically, three types of quartz were separated (Întorsureanu et al., 1985):

- white-yellowish quartz with greenish tint (containing gold particles);

- grey-greenish brecciated quartz accompanied by secondary minerals formed along the fissures (chlorite, carbonates, neoformed quartz etc.; gold is present as disseminations);

- white-milky quartz (lacking gold particles).

The gold included in the first two types of quartz is present as fine grains $(0.072-0,120 \mathrm{~mm}$ in size; PI. III, fig. 1$)$. The white-milky quartz is a metamorphic segregated type of a late generation, that explain the lack of gold. Pyrite occurs sporadically as fine micrometric grains often oxidised (limonite), while chalcopyrite is partly substituted by chalcocite; galena and sphalerite occur only accidentally.

\section{The gold-containing mineralization from Someşul Rece (Gilău} Mountains)

This occurrenVce consists of lenses of gold-containing quartz located in the Mieilor Hill, Bă ilor Creek and Seacă Valley areas, that are congruent effluents of Someșul Rece Valley (aligned along a tectonic plane), upstream

\footnotetext{
${ }^{4}$ V. Lucca (1949). Raport geologic minier asupra regiunii Bozovici (12 p, 5 schiț e). Arhiv. Nat ion. Deva.

${ }^{5}$ V. Lucca, Giurgiu C., Haida H., Patriciu V., Belecan G., Kelemen Ș. (1950). Proces verbal asupra lucră rilor din reg. Bozovici (Banat) (fost în Arhiv. Intr. Min. Barza, Brad). 106
} 
from Someșul Rece village (PI. I, fig. 1) ${ }^{6}$. From a geological point of view, the Biharia metabasite Series with local dolomitic sequences tectonically overlaying a retromorphous term (mica schistes with garnets) of the Somes Series, probably Somes lithogrupe, is worth to mention; this represents the tectonic setting from Somesul Rece, that concentrated the shear zone - type gold mineralizations. The dolomitic sequences is most probably of a reef - type. The presence of the quartz veins in the dolomite is the result of the tectono - metamorphic mobilization of silica $\left(\mathrm{SiO}_{2}\right)(\mathrm{PI}$. II, fig. 1).

The exploration and mining works were realised during a short interval in the first half of the XIX century and subsequently in several stages (PI. I, fig. 2). The most recent mining activity was conducted by TRANSGEX - Cluj. The gold mineralization consists of lenses of quartz located in a complex of metamorphic rocks (quartzitic-feldspatic-sericitic schists (Cobârzan and Că praș, 1997), or in porphyroids and their associated epimetamorphic rocks (Mârza, 1999). The bodies of gold-containing quartz are sometimes aligned parallel or other times discordant to the foliation of the host rock, and they can be isolated or continuous. The length of the continuous vein-like areas varies from several meters to tens of meters, rarely reaching $100 \mathrm{~m}$, while the thickness never exceeds $2.5 \mathrm{~m}$. Within the quartz crystals, gold lamellae (exceptionally visible by naked eye), and sulphides (pyrite, chalcopyrite, sphalerite, galena, tetrahedrite, chalcocite, covellite etc.) are disseminated. Sporadically siderite is also present. Locally, concentrations of sulphides are accompanied by larger amounts of gold.

Genetically, the mineralizations from Someșul Rece were attributed to: older granitic sources (Lucca, 1936), banatites (Hesselman, 1967) ${ }^{7}$, post-banatitic hydrothermalism (Muresan, 1980), and more recently to the shear zones - type (Udubașa and Hann, 1988; Dimitrescu and Mihaela Dimitrescu, 1995; Mârza, 1999).

\section{Fluid inclusions}

The samples that were investigated for their fluid inclusion content from both areas were collected from old, but still accessible mines, from waste dumps, from drill cores and from outcrops. Taking into account the similarities between the parameters of the fluid inclusions (petrography, homogenisation temperature, Th, and decrepitation temperature, Td, chemistry) and the conclusions that can be drawn accordingly, below a common presentation is given. However, the specific features will be emphasized.

Four types of fluid inclusions were identified in the studied materials, distinguished by shape, degree of filling of the vacuoles, and phase composition:

\footnotetext{
${ }^{6}$ Photos in the field were realized by Lecturer dr. Că lin Tă maș (Plates I, II)., whom we express our acknowledgments.

7 Hesselman A. (1967). Raport geologic asupra lucră rilor cu caracter de prospecțiune și referinț ă, executate de ISEM în perioada anilor 1961-1962 în sectoarele: V. Bedeci și Someșul Rece, regiunea Cluj. Arhiv. IGG București.
} 
- A-type consists of biphasic $(\mathrm{L}+\mathrm{V})$ aqueous inclusions represented by negative, irregular crystal shapes ( PI. III, figs. 2 and 3);

- AS-type is represented by aqueous $(L+V)$ solution, and efflorescences and aggregates of daughter minerals with a reduced birefringence;

- AC-type, the most frequent one in the gold-containing quartz in both areas; it corresponds to the aqueous solutions of $\mathrm{CO}_{2}$ (PI. III, fig. 4 and PI. IV, figs. 1 and 2). In comparison, an AC-type inclusion in quartz from Tincova, Banat is presented (PI. IV, fig. 3);

- C-type contains mono- and biphasic fluid inclusions of $\mathrm{CO}_{2}$ (liquid + vapours) (fig. 1).

\section{Microthermometric data}

The C-type inclusions are characterised by homogenisation temperatures (Th) in liquid phase between $18^{\circ}$ and $29^{\circ} \mathrm{C}$, below the critical value of $\mathrm{CO}_{2}$ (fig. $1 \mathrm{~A}$ ). For the A-type inclusions temperatures between $90^{\circ}$ and $200^{\circ} \mathrm{C}$ are common, while to AS-type corresponds the range $125^{\circ}-250^{\circ} \mathrm{C}$. The efflorescences and particles of birefringent daughter minerals, are homogenised in liquid phase between $135^{\circ}$ and $260^{\circ} \mathrm{C}$. AC-type, that characterizes the aqueous $\mathrm{CO}_{2}$ solutions, shows two distinctive Th intervals: one corresponding to the transformation of $\mathrm{CO}_{2}$ (gas) into $\mathrm{CO}_{2}$ (liquid), between $18-26^{\circ} \mathrm{C}$, and a second one between $283-$ $332^{\circ} \mathrm{C}$, with a maximum between $300-310^{\circ} \mathrm{C}$ indicating the total homogenisation temperature. (fig. $1 \mathrm{~B}$ ). The latter values correspond to the transformation of liquid $\mathrm{CO}_{2}$ into aqueous solution, or to that of aqueous solution into liquid $\mathrm{CO}_{2}$.

A histogram built on the basis of 95 Th measurements of the AC-type fluid inclusions in the gold-containing quartz from Someșul Rece, indicating the limits and the maximum temperature frequency is presented in fig. 2. Taking into account the abundance of $\mathrm{CO}_{2}$ in the inclusions one can plead for the gold precipitation from hydrothermal-metamorphic solutions at high pressures and at depth below $5 \mathrm{~km}$. After applying a correction of $17^{\circ} \mathrm{C} / \mathrm{km}$ according to the thermal gradient $\left(30^{\circ} \mathrm{Cl} \mathrm{km}\right.$, Savul and Pomârleanu, 1960) the maximum frequency of $\mathrm{Th}\left(305-310^{\circ} \mathrm{C}\right)$ corresponds to the interval between $380-390^{\circ} \mathrm{C}$. This interval is within the range of temperatures calculated for the metamorphic processes for the sericitic schists of Arada Series (Borcos and Dimitrescu, 1969).

The intervals corresponding to the decrepitation temperatures $(\mathrm{Td})$ of the fluid inclusions in the first two gold-containing quartz types from Slă tinic (Bozovici) are represented in the decrepitograms (fig. 3). The maximum temperature frequency ranging between $380^{\circ}$ and $420^{\circ} \mathrm{C}$ is close to the values calculated by taking into account the thermal gradient $\left(30^{\circ} \mathrm{C} / \mathrm{km}\right)$.

Th values for the $\mathrm{CO}_{2}$-containing inclusions lower than the critical value of $\mathrm{CO}_{2}$ are due to the presence of $\mathrm{CH}_{4}$ with $\mathrm{T}_{\mathrm{C}}=-83^{\circ} \mathrm{C}$ and of $\mathrm{N}_{2}$ with $\mathrm{T}_{\mathrm{C}}=$ $147^{\circ} \mathrm{C}$, as components easily miscible with $\mathrm{CO}_{2}$.

A specific feature concerning the chemical composition of the fluid inclusions is represented by the $\mathrm{CO}_{2} / \mathrm{HO}_{2}$ ratio, ranging between 0.50 and 
IMPLICATIONS RESULTING FROM THE STUDY OF FLUID INCLUSIONS IN THE SHEAR ZONE-TYPE ...

0.772 for the samples from Slă tinic, and between 0.35 and 0.70 for Somesul Rece samples (analysed by using gas chromatography). The molar $\mathrm{CO}_{2} / \mathrm{HO}_{2}$ ratio in the inclusions from Slă tinic samples as compared to that from Someșul Rece samples is also determined by the higher volume of $\mathrm{CO}_{2}$. 


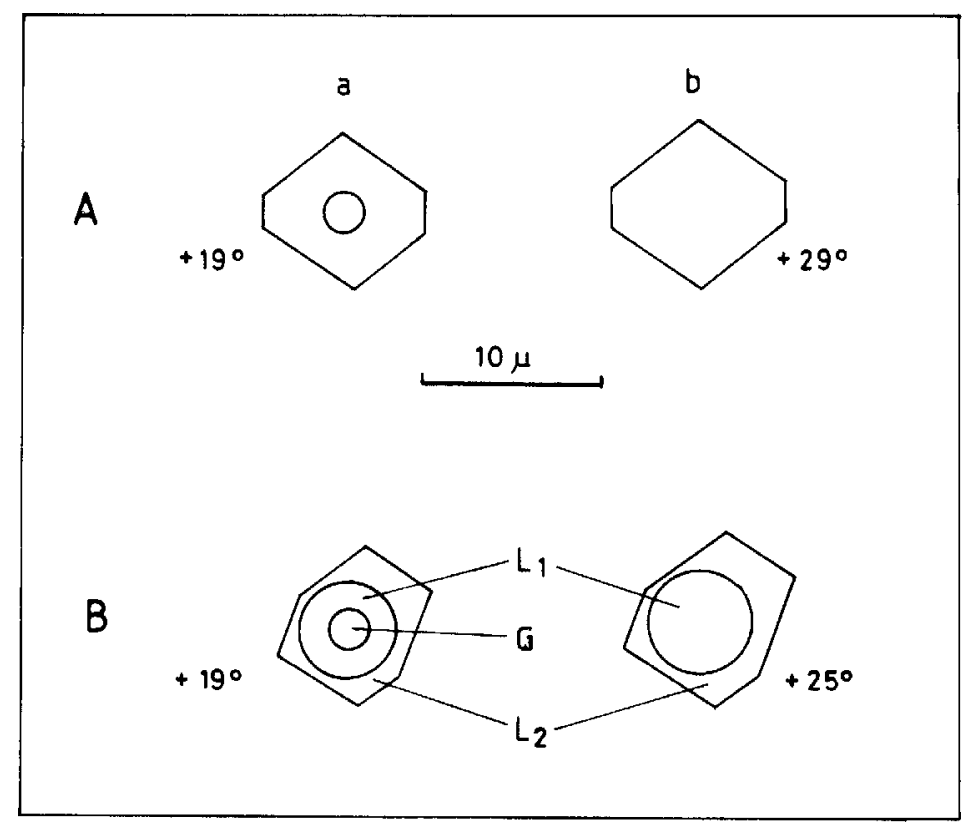

Fig. 1. A - The behaviour of a fluid inclusion of C-type: $\mathbf{a}$, at $+19^{\circ} \mathbf{C}$ and $\mathbf{b}$, at $+29^{\circ} \mathrm{C}$; B - behaviour of an inclusion of a AC-type: at $+19^{0} \mathrm{C}$ three phases can be distinguished $-\mathrm{CO}_{2}$ vapours $(G)+$ liquid $\mathrm{CO}_{2}\left(\mathrm{~L}_{1}\right)+$ aqueous solution $\left(L_{2}\right)$, while at $25^{\circ} \mathrm{C}$ the triphasic environment turns into a biphasic one.

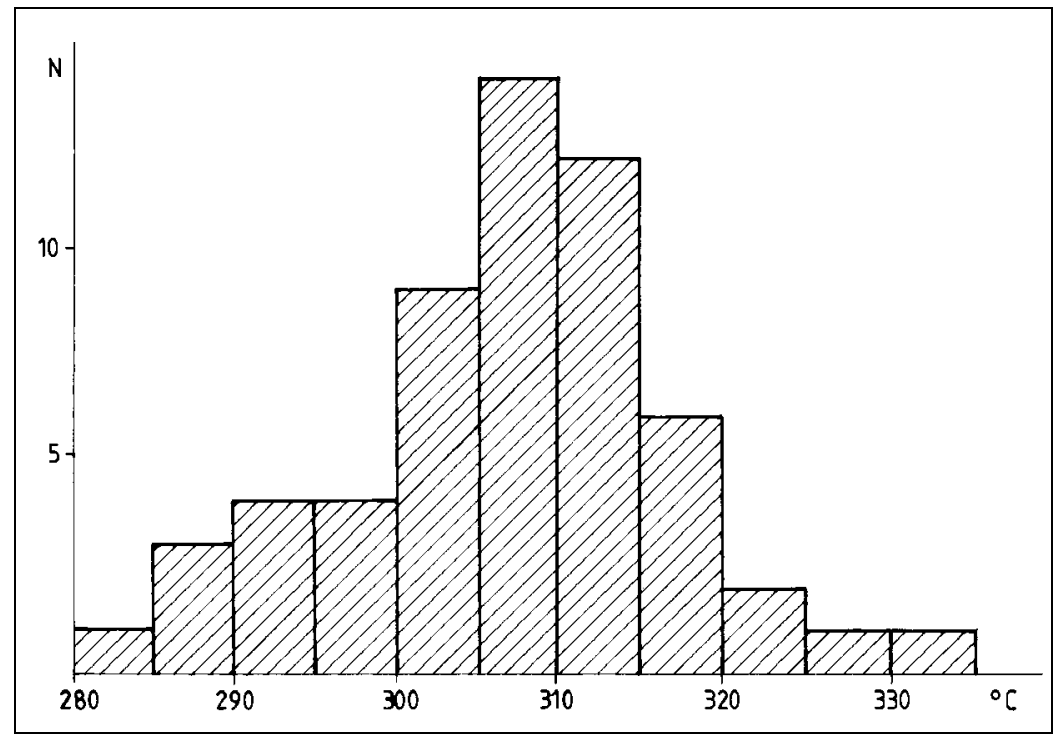

Fig. 2. Th histogram of the AC-type inclusions in the gold-containing quartz from Somesul Rece. 


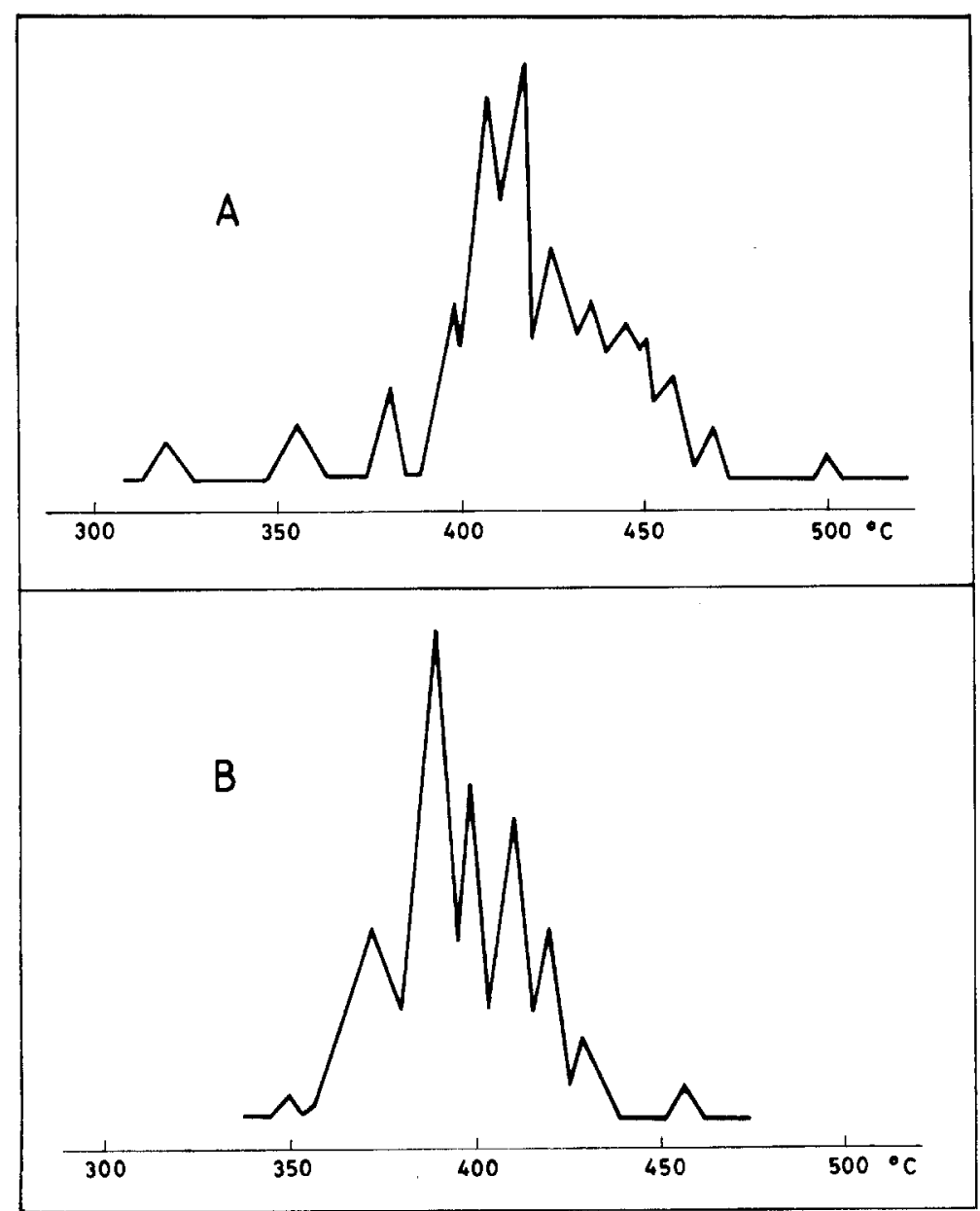

Fig. 3. Decrepitograms of the gold-containing quartz from Slă tinic (Bozovici): A - greygreenish quartz (waste dump), B - white-yellowish quartz (vein).

The presence of efflorescences and highly birefringent microcrystals (daughter minerals) in the A and AS-type inclusions, as well as their dissolution in the temperature range $135-260^{\circ} \mathrm{C}$ prove the presence of nahcolithe in these inclusions, as daughter mineral; Samson et al. (1977) identified it in similar mineralizations.

The microthermometric measurements performed at high temperatures and at freezing temperature evidenced specific correlations between Th, Te, and $\mathrm{Tm}$ and a variable salinity $(2-14 \mathrm{wt} \% \mathrm{NaCl}$ equivalent). The specific parameters obtained from the inclusions in the gold-containing quartz from Slă tinic (Bozovici) and Someșul Rece (Gilă u) are presented in table 1. 
Table 1.

The type, origin, and the specific values of Th and Td for the fluid inclusions in the gold-containing quartz from Slă tinic (Bozovici) and Someșul Rece (Gilă u)

\begin{tabular}{|c|c|c|c|c|c|}
\hline \multirow{2}{*}{ Category } & \multirow{2}{*}{ Type } & \multirow{2}{*}{ Phases } & \multirow{2}{*}{ Origin } & \multicolumn{2}{|c|}{ Temperature ${ }^{\circ} \mathrm{C}$} \\
\hline & & & & $T^{*}{ }^{*}$ & Td \\
\hline \multirow[b]{2}{*}{ Aqueous } & A & $\mathrm{L}+\mathrm{V}^{*}$ & $\mathrm{~s}$ & $90-200$ & $300-460$ \\
\hline & AS & $\begin{array}{l}\mathrm{L}+\mathrm{V}+\text { nahcolithe }{ }^{* *} \text {, rarely birefringent } \\
\text { crystals }\end{array}$ & $p+s$ & $125-250$ & $300-460$ \\
\hline $\begin{array}{l}\text { Bicarbonate } \\
\text { aqueous }\end{array}$ & $A C$ & Triphasic, aqueous bicarbonate & $p+s$ & 283-332 & 420 \\
\hline Bicarbonate & $\mathrm{C}$ & Mono- and biphasic, bicarbonate & $p$ & $18-28$ & $380-420$ \\
\hline
\end{tabular}

* $\mathrm{L}$ - liquid, V - vapours; $\mathrm{p}$ - primary, $\mathrm{s}$ - secondary; Th - homogenisation temperature, $\mathrm{Td}$ - decrepitation temperature;

** nahcolithe crystals are dissolved between $140-260^{\circ} \mathrm{C}$

\section{Conclusions}

- Petrographically, the lens-shaped, vein-like body from Slă tinic is located in amphibolites and amphibolite schists corresponding to metabasites (Intorsureanu et al., 1988), while the gold-containing quartz lenses from Someșul Rece are spatially associated mainly to the porphyroids and metabasites of the Biharia or Codru series. Thus, there are similitudes concerning the metamorphic petrometallogeny of the two occurrences.

- Based on the shape, content, origin and geothermometric parameters etc., the studied fluid inclusions of the two occurrences are similar; the specific difference consists in a higher frequency of the $\mathrm{CO}_{2}$ inclusions, higher values for the molar $\mathrm{CO}_{2} / \mathrm{HO}_{2}$ ratio and other volatile components such as $\mathrm{CH}_{4}, \mathrm{~N}_{2}$ etc.; the microcrystals (daughter minerals) from the fluid inclusions correspond mineralogically to nahcolithe $\left(\mathrm{NaHCO}_{3}\right)$.

-The maximum temperature of formation of gold and the hydrothermalmetamorphicmetallic assemblage in general was determined to be above $350^{\circ} \mathrm{C}$.

- Starting from these results, other shear zones enriched in gold and silver might be identified and delimited in the metamorphic terrains of the Romanian Carpathians. This would involve the common research of experts in various fields of geosciences (tectonics, geophysics, petrography, metallogeny, geochemistry, geothermometry etc. $)^{8}$.

\section{REFERENCES}

Borcoș M., Dimitrescu R. (1969). Contribut ii la determinarea condit iilor fizice ale metamorfismului regional din Munții Apuseni. Stud. și cercet. geol., geofiz., geograf., Seria Geologie, 14, 2, 363-374, București.

Cobârzan A., Că praș D. (1997). Mineralizț iile auro-argentifere asociate epimetamorfitelor din Apusenii nordici. Rev. Min., 3, 6-9, București.

\footnotetext{
${ }^{8}$ We express our special thanks to Dr. Dana Pop for the English version of this paper. 112
} 
Intorsureanu I., Pomârleanu V., Neguț Gh., Serafimovici V., Streangă V., Anastase Ș, Stefă nescu A., Voicu M. (1985).Contributions à la connaisance de la minéralizations aurifère de Slă tinic, Bozovici (Banat). D. S. Inst. Geol. Geofiz., LXIX/2 (1982), 41-59, București.

Lucca V. (1936). Regiunea auriferă de la Someșul Rece (jud. Cluj). Rev. Muz. Geol. Min., Univ. Cluj, VI, 1-2, 155-164, Cluj.

Mârza I. (1999). Geneza ză că mintelor de origine magmatică. Vol. 4. Metalogenia Hidrotermală . Presa Universitară Clujeană , 486 p, Cluj-Napoca.

Mureșan I. (1980). Geologia și petrografia bordurii de nord-vest a Munt ilor Gilă u. Edit. Acad. R.S. România, 127 p., București.

Popescu Gh. C., Sava L. (1994). The study of fluid incluzions from shear zones in North Sebes Mts.: estimating level of erosion. Anal. Univ. București., Geol. (Suppl. Abstr. Vol.), XLVIII, 26-27, București.

Popescu Gh. C., Predeteanu D. (1999). Preliminary study of fluid inclusions from gold-quartz veins of Leaota Mts., Anal. Univ. Bucuresti. Mineralogy, petrology, metalogeny and geochemistry International Symposium. Abstr. Vol. (Suppl., XLVIII, 94-95, București.

Predeteanu D., Popescu Gh. C. (2000). Chemical analyses of fluid inclusions by SEM/EDA in the gold quartz veins, Leaota Mountains. Rom. J. Min. Deposits, V, 79, suppl. 1, 89-91, Bucuresti.

Samson I. M., Holm P. E. (1997). Hydrothermal evolution of auriferrous shear zones, Wawa, Ontario. Econ. Geol., V, 92, 325-342.

Savul M., Pomârleanu V. (1960). Paleogeothermometrishes Profil den Ostkarpatehen den differienzierten Quartz der kristallinien Schiefer bettrefend. Anal. St. Univ. "Al.I.Cuza" lași, V, VI/2, 335-344, lași.

Udubașa Gh., Hann P.H. (1988). A shear - zone related Cu-Au ore occurrence: Valea lui Stan, South Carpathians. D. S. Inst. Geol. Geofiz., 72-73/2, 259-282, București.

PI. I.

Fig. 1. Mieilor Hill (left side of Someșului Rece river) with the outcrop of dolomites included in Biharia Series.

Fig. 2. Exploration mine in Mieilor Hill.

PI. II.

Fig. 1. Dolomite (Biharia Series) crossed by a dense network of quartz veins.

Fig. 2. Microbended porphyroid rocks (Biharia Series, left side of Someșului Rece river).

PI. III.

Fig. 1. Gold included in quartz (Slă tinic, Bozovici; Intorsureanu et al., 1985); N II; 180 x.

Fig. 2. Fluid inclusions of A-type in the gold-containing quartz from Someșul Rece.

Fig. 3. Fluid inclusions of $A$-type $(L+V)$ in the gold-containing quartz from Slă tinic (Bozovici).

Fig. 4 Fluid inclusions of AC-type in the gold-containing quartz from Slă tinic (Bozovici).

PI. IV.

Fluid inclusions of AC-type: from Valea Seacă (Someșul Rece, fig. 1, 2) and from Tincova (Banat, fig. 3; for comparison), where $\mathrm{CO}_{2}$ dominates and a fine pellicle of aqueous solution is also present. 
VASILE POMÂRLEANU, IOAN MÂRZA

\section{PI. I}
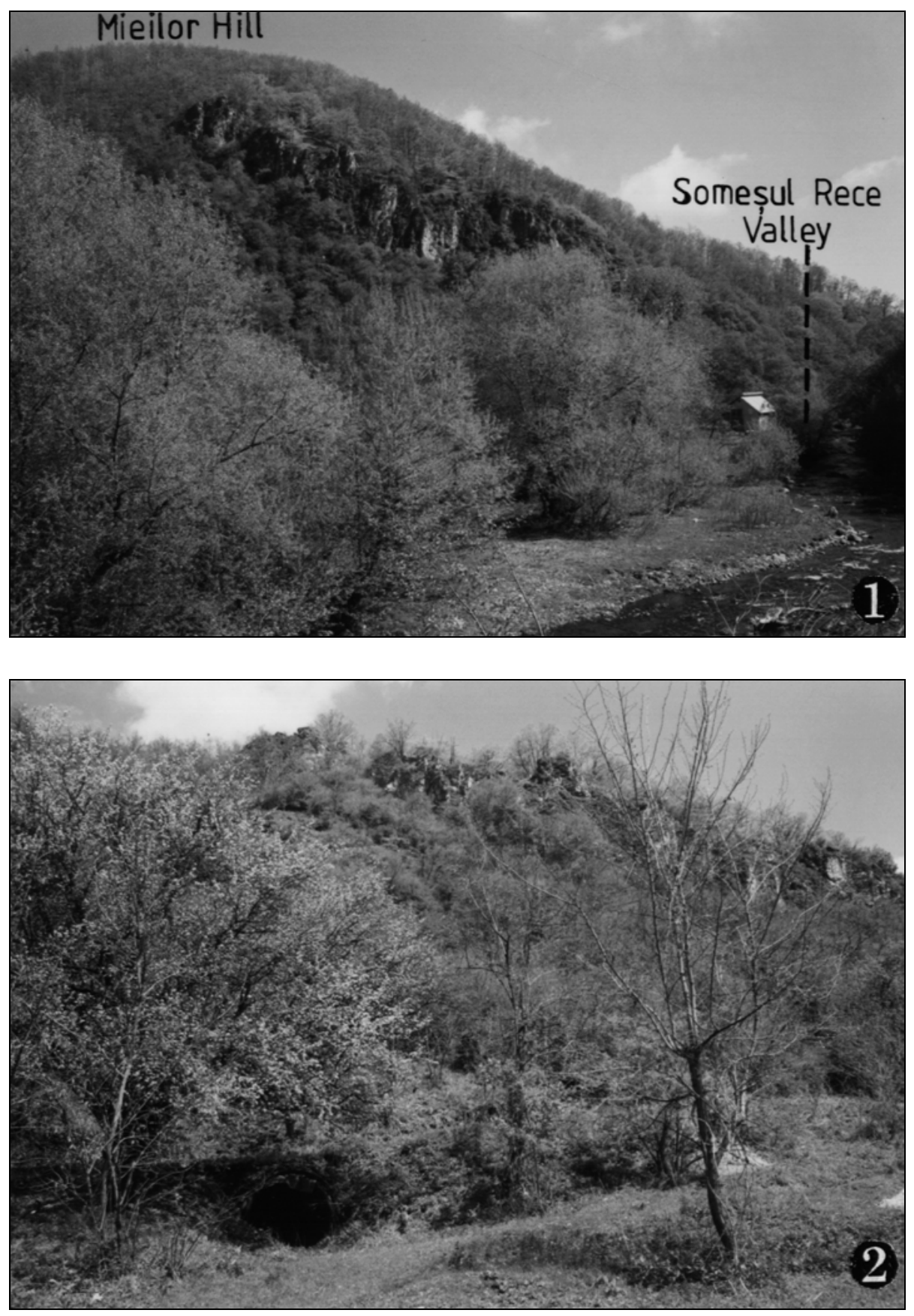
IMPLICATIONS RESULTING FROM THE STUDY OF FLUID INCLUSIONS IN THE SHEAR ZONE-TYPE ...

\section{PI. II}
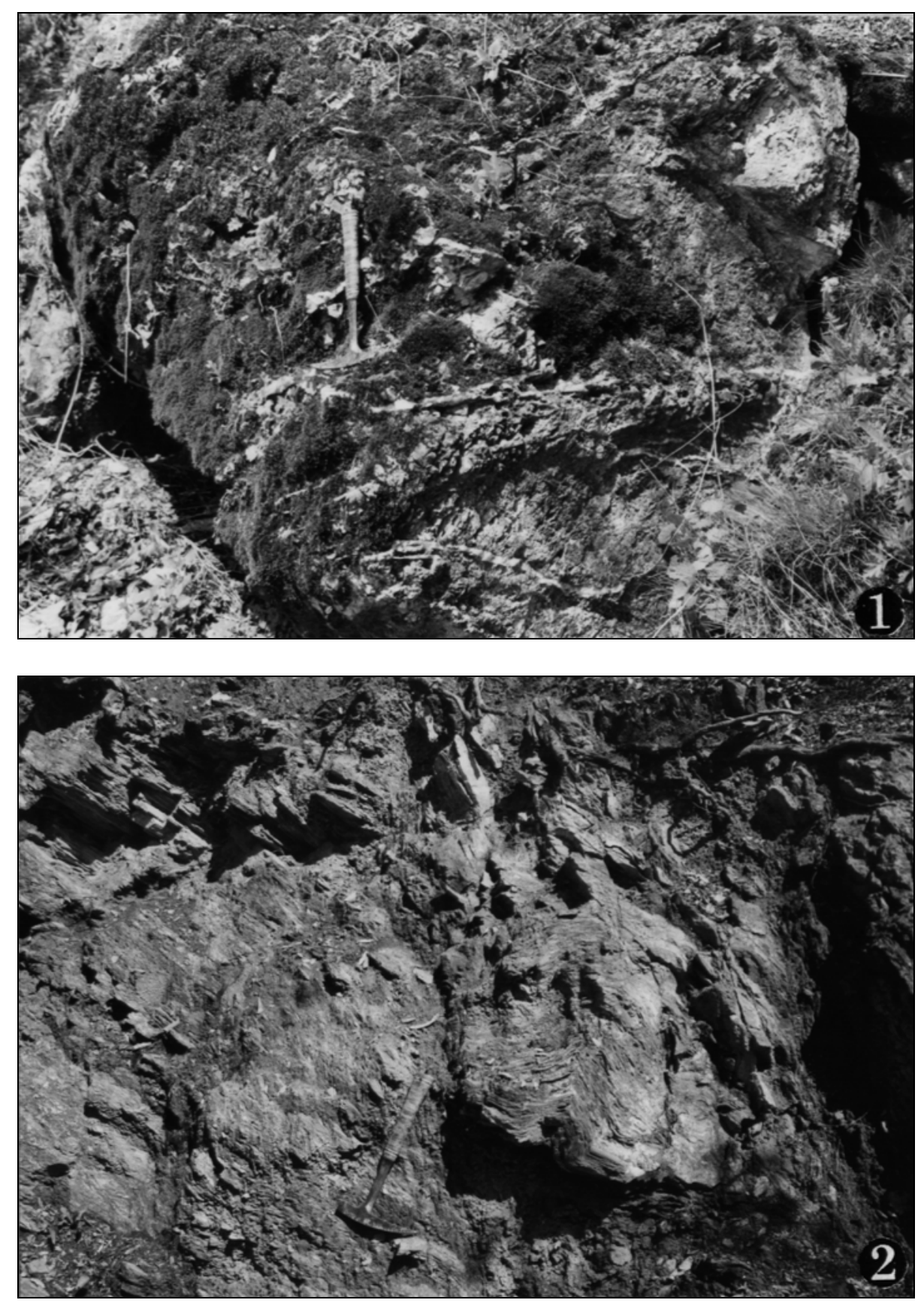
VASILE POMÂRLEANU, IOAN MÂRZA

PI. III
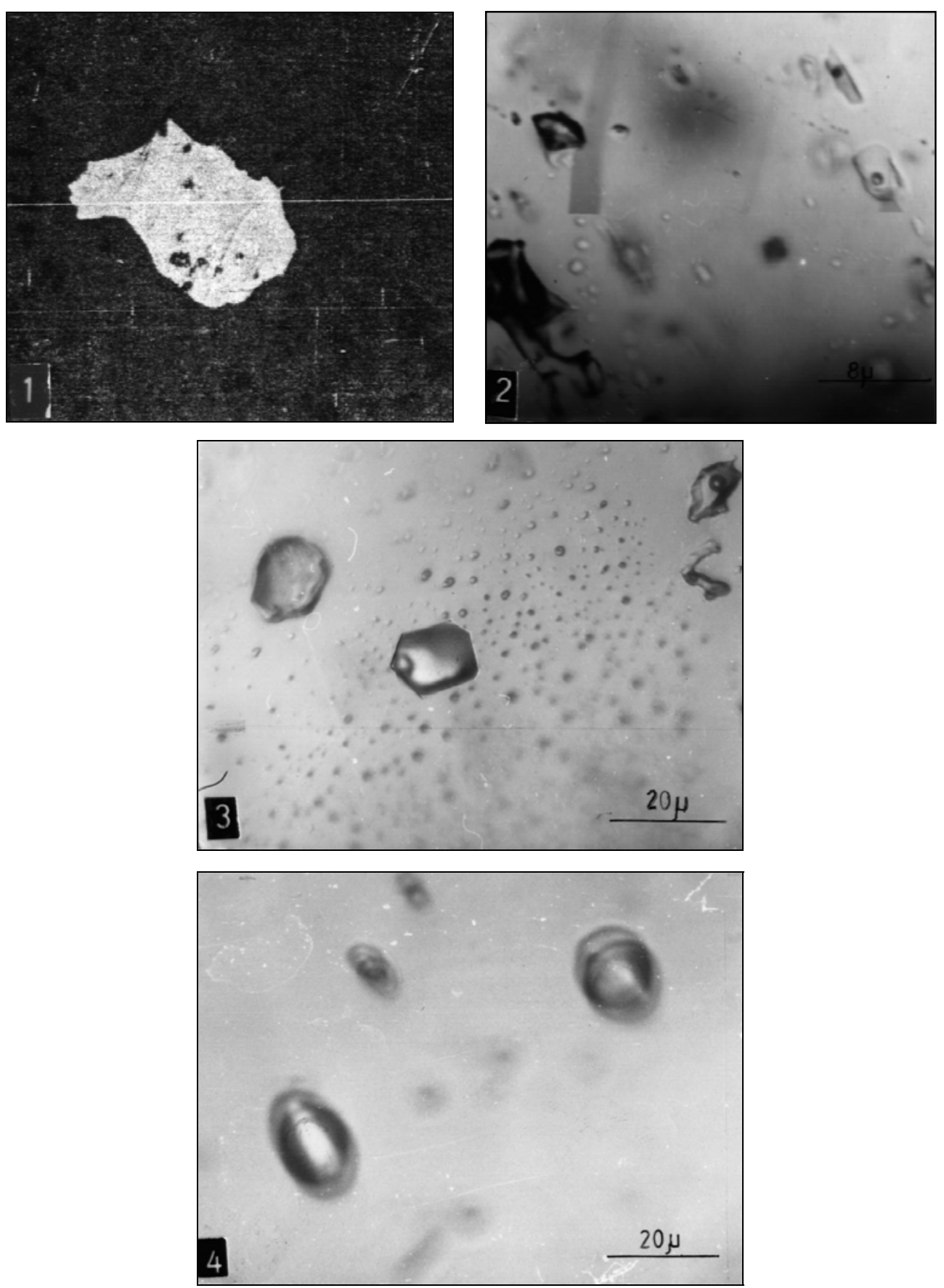
IMPLICATIONS RESULTING FROM THE STUDY OF FLUID INCLUSIONS IN THE SHEAR ZONE-TYPE ...

PI. IV
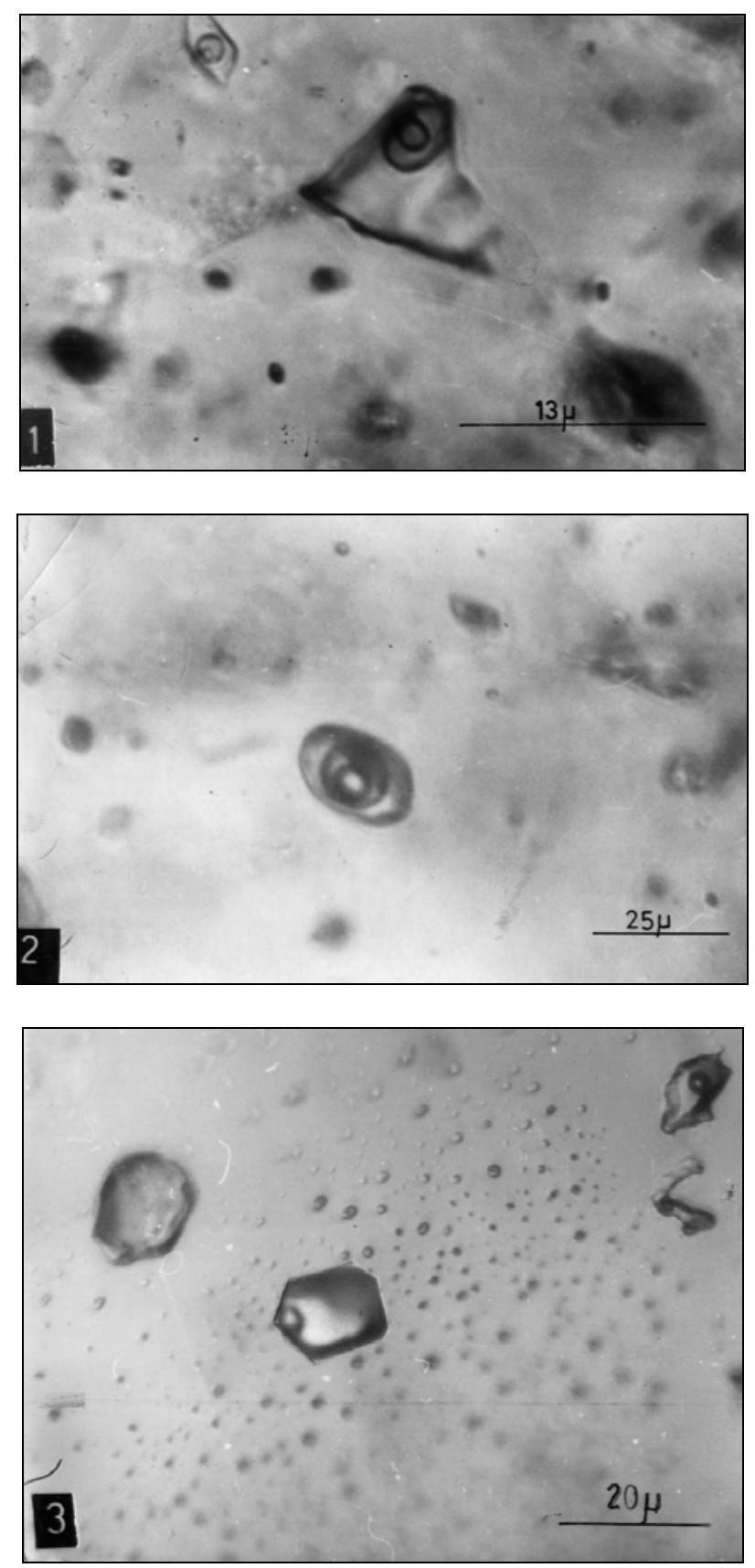